fibrous nature of browse resources, as observed in most of the villages under study.

Differences in neutral detergent fibre and acid detergent fibre (ADF) contents and cellulose contents in the browse materials were not observed due to similar nature and hardiness of the collected grasses. However, higher content of $\mathrm{ADF}$ revealed that the plant materials were fibrous and hence less digestible for livestock. Grasses were hard to cut, reflecting their fibrous nature and thereby expected to have lower palatability for various livestock species. Differences in hemicellulose and lignin content were observed, which can be attributed to differences in the maturity of plant species in the grasslands. Domesticated species, especially yak, pashmina goat, pony and horse were found to sustain on these grasslands, reflecting their better fibre digesting ability. Under harsh climatic conditions, only those grasses survive which can cope with aridity, extreme diurnal temperature fluctuations, strong winds and abrasion, solifluction at higher altitudes and salinity at lower altitudes, nutrient-poor soils and a short growing season. Under such conditions, productivity is generally low and the vegetation is sparse $^{9}$. Growing season is confined to a short period from June to August in summer, and alpine steppe communities with medium to sparse cover $(20 \%)$ dominate the vegetation. Dominant grass species like Carex and Stipa have high fibre content. Cold deserts of the Himalaya have short-lived species, which provide cover for $2-$ 3 months. Grazing resources comprise $14.2 \%$ of land in Leh and $16.8 \%$ in Kargil district, Ladakh. Lower productivity of grasslands could also be attributed to high grazing pressure during sample collection, as this study was conducted during early winter when the crop residues available in households or fields are minimal.

On the basis of the present study, it can be concluded that grasses in the Ladakh region have high fibre content with poor nutritional value for livestock. Productivity of grasslands differs from one area to another, perhaps due to variation in the natural terrain, soil texture and salinization of the land that also affect the nutritional composition of the grasses.

1. Tewari, J. C., Pareek, K., Raghuvanshi, M. S., Kumar, P. and Roy, M. M., Fodder production system a major challenge in cold arid region of Ladakh, India. MOJ Econ. Environ. Sci., 2016, 1, 22-28.

2. Rawat, G. S. and Adhikari, B. S., Floristics and distribution of plant communities across moisture and topographic gradients in Tso Kar Basin, Chanthang Plateau, Eastern Ladakh. Artic. Antarc. Alp. Res., 2005, 37, 539-544.

3. AOAC, Official Methods of Analysis, Association of Official Analytical Chemists, Arlington, VA, USA, 1995, 16th edn.

4. Vansoest, P. J. and Robertson, J. B., A Laboratory Manual of Animal Science, No. 612, Cornell University, Ithaca, USA, 1998.

5. Statistical Packages for the Social Sciences, Base 10, SPSS Software Products, SPSS Inc, Chicago, IL, USA, 1997.

6. Cox, J. R., Martin-R, M. H., Ibarra-F, F. A., Fourie, J. H., Rethman, N. F. G. and Wilcox, D. G., The influence of climate and soils on the distribution of four African grasses. J. Range Manage., 1988, 41, $127-139$.
7. Misra, C., High altitude survival: conflicts between pastoralism and wildlife in Trans Himalaya. Doctoral thesis, Wageningen University, The Netherlands, 2001

8. Sawal, R. K. and Sharma, K. C., Biomass evaluation of pasture in hot arid Rajasthan. Indian J. Small Rumin., 2013, 19, 56-60.

9. Dvorsky, M., J. Dolezal, J., Bello, F. De., Klimesova, J. and Klimes, L., Vegetation types of East Ladakh: species and growth form composition along main environmental gradients. Appl. Veg. Sci., 2010, 1, $1-17$.

ACKNOWLEDGEMENT. Financial assistance received under a DST-funded research project on the Taskforce on Himalayan Agriculture (National Mission for Sustaining the Himalayan Ecosystem) is acknowledged.

Received 30 June 2020; accepted 23 July 2020

doi: $10.18520 / \mathrm{cs} / \mathrm{v} 119 / \mathrm{i} 7 / 1195-1197$

\section{Manoeuvring prospective rhizosphere- competent bacteria for invigorating growth in chickpea}

\author{
Poonam Kumari ${ }^{1}$ and Veena Khanna ${ }^{2}$ \\ ${ }^{1}$ Department of Microbiology, and \\ ${ }^{2}$ Department of Plant Breeding and Genetics, \\ Punjab Agricultural University, Ludhiana 141 004, India
}

The exploration for beneficial rhizosphere-competent bacteria commenced with screening isolated strains for plant growth-promoting attributes, including secretion of indole-3-acetic acid, gibberellins, 1-aminocyclopropane-1-carboxylic acid deaminase, solubilization of phosphate and zinc. The secretion of flavonoid-like compounds revealed quantitative as well qualitative variability among the isolates as their culture supernatant exhibited several fluorescent compounds on TLC plates with different mobilities. Inoculation of seeds with effective isolates under axenic condition enhanced plant growth and induced flavanoids secretion from roots, although the effect was only quantitative. The prospective bioinoculants exhibited competence in lieu of intrinsic antibiotic resistance, amylase production, biofilm formation, root infectivity, salinity tolerance and exopolysaccharide production. Seed bacterization with potential isolates alone and in consortium with rhizobia stimulated growth of chickpea plants under controlled condition.

*For correspondence. (e-mail: poonam15sep@gmail.com) 
Keywords: Biofilms, chickpea, flavonoids, plant growth, rhizobacteria.

THE rhizo-microbiome supports a diverse population of microbes which can benefit plants ${ }^{1}$. Among the microbial communities inhabiting the soil, root-associated beneficial bacteria, known as plant-growth promoting rhizobacteria $(\text { PGPR })^{2}$, have been documented as the most predominant group that promotes plant health through nitrogen-fixation, nutrient acquisition and assimilation, secretion of phytohormones, suppression of plant diseases and host induction for the production of signal substances to other symbionts, i.e. flavonoids ${ }^{3}$. Nonetheless, successful application of bioinoculants entails an intimate association between PGPR and the host plant ${ }^{3}$, which depends on the competence and colonization pattern of the bacteria. The uneven relationship between associated PGPR and plants has been attributed to climatic conditions, soil properties or the composition or activity of native microbial soil flora that may affect rhizobacterial growth and hence exert their effect on the plant ${ }^{1}$. The best growth-promoting interaction between PGPR and plants under field conditions can be attained by evaluating the rhizobacterial effects on plants and factors affecting their relationship, including the presence of other microorganisms ${ }^{4}$. Therefore, it is necessary to develop efficient strains that are competent as well as able to survive and colonize the rhizospheric soil under field conditions. One possible approach is to explore soil microbial diversity having plant growthpromoting traits and well adapted to a particular environment. Keeping this in view, the present study aimed to identify rhizosphere competent bacterial isolates for their multiple plant growth-promoting activities and to study their effect on growth parameters of chickpea.

Rhizobacteria were isolated from chickpea fields in the vicinity of Punjab, Uttar Pradesh, Chhattisgarh, Himachal Pradesh and West Bengal, India. The rhizosphere samples were collected by carefully removing the plants using a shovel and the soil loosely adhered to the root was taken as rhizosphere soil. This collected soil was serially diluted in sterile water and spread on nutrient agar and King's B media. The plates were incubated at $30^{\circ} \mathrm{C}$ for $24 \mathrm{~h}$. The morphologically different colonies were selected, purified by subculturing and maintained on the respective slants at $4^{\circ}-5^{\circ} \mathrm{C}$. Chickpea nodulating Mesorhizobium ciceri was procured from the Department of Microbiology, Punjab Agricultural University and maintained on yeast extract mannitol agar.

Screening of all the isolates for phosphate solubilization was done by inoculating overnight-grown bacterial cultures on plates containing NBRIP (National Botanical Research Institute's phosphate growth medium) medium ${ }^{5}$, followed by incubation at $28^{\circ} \mathrm{C}$ for 5 days. The colonies were observed for the formation of yellow coloration around them, and P-solubilization index was calculated as the sum of colony diameter and halo zone diameter/ colony diameter. The zinc-solubilization ability was tested using modified Pikovskaya medium containing $0.1 \%$ insoluble $\mathrm{ZnO}$ and halo around inoculated bacteria was recorded. Zinc solubilization index was then calculated.

Quantitative estimation of indole-3-acetic acid (IAA) production by rhizobacteria was done by inoculating bacterial cultures in Luria broth supplemented without and with (3 mM) tryptophan (Trp) followed by incubation for $72 \mathrm{~h}$ at $30^{\circ} \mathrm{C}$. Cultures were then centrifuged and $2 \mathrm{ml}$ supernatant was mixed with two drops of orthophosphoric acid followed by $4 \mathrm{ml}$ of the Salkowski reagent. After incubation for $20 \mathrm{~min}$ at room temperature, the pink colour developed was read at $530 \mathrm{~nm}$ (ref. 6).

For gibberellic acid $\left(\mathrm{GA}_{3}\right)$ production ${ }^{7}$, bacterial cultures inoculated in nutrient broth and incubated at $37^{\circ} \mathrm{C}$ for seven days were centrifuged at $8000 \mathrm{rpm}$ for $10 \mathrm{~min}$. Next, $15 \mathrm{ml}$ of the supernatant was mixed with $2 \mathrm{ml}$ of zinc acetate solution $(21.9 \mathrm{~g}$ of zinc acetate was mixed with $80 \mathrm{ml}$ of distilled water, and $1 \mathrm{ml}$ of glacial acetic acid was added and the volume made up to $100 \mathrm{ml}$ with distilled water). After $2 \mathrm{~min}, 2 \mathrm{ml}$ of potassium ferrocyanide solution (10.6 $\mathrm{g}$ of potassium ferrocyanide in $100 \mathrm{ml}$ of distilled water) was added and centrifuged at $8000 \mathrm{rpm}$ for $10 \mathrm{~min}$. Next, $5 \mathrm{ml}$ of supernatant was added to $5 \mathrm{ml}$ of $30 \% \mathrm{HCL}$ and the mixture was incubated at $27^{\circ} \mathrm{C}$ for 75 min. The blank was prepared with 5\% HCL. Absorbance was read at $254 \mathrm{~nm}$ in a UV-VIS spectrophotometer. Standard curve was prepared using $\mathrm{GA}_{3}$ solutions of known quantities and the amount of $\mathrm{GA}_{3}$ produced by the culture was calculated and expressed as $\mu \mathrm{g} 25 \mathrm{ml}^{-1}$ broth $^{8}$. For the estimation of 1-aminocyclopropane-1carboxylate deaminase (ACC-deaminase) activity, bacterial cultures were grown overnight in $10 \mathrm{ml}$ of nutrient broth and the pellet harvested by centrifugation was washed with normal saline and suspended in $7.5 \mathrm{ml}$ of DF medium containing $5 \mathrm{mM}$ of ACC deaminase. After incubation for $24 \mathrm{~h}$ at $28^{\circ} \mathrm{C}$ with shaking, the cells were centrifuged at $8000 \mathrm{rpm}$ for $10 \mathrm{~min}$ at $4^{\circ} \mathrm{C}$. The pellet was suspended in $1 \mathrm{ml}$ of $0.1 \mathrm{M}$ Tris $-\mathrm{HCl}(\mathrm{pH} \mathrm{7.6)}$ and again harvested by centrifugation at $15,000 \mathrm{rpm}$ for $15 \mathrm{~min}$ to be resuspended in $600 \mu \mathrm{l}$ of $0.1 \mathrm{M}$ Tris $-\mathrm{HCl}(\mathrm{pH} 8.5)$. Next, $30 \mu \mathrm{l}$ of toluene was added and tube was kept at $4^{\circ} \mathrm{C}$ for $1 \mathrm{~h}$ and then centrifuged at $1200 \mathrm{rpm}$ for $10 \mathrm{~min}$ at $4{ }^{\circ} \mathrm{C}$. To $200 \mu \mathrm{l}$ of toluenized cells, $20 \mu \mathrm{l}$ of $0.5 \mathrm{M} \mathrm{ACC}$ deaminase was added, vortexed and incubated at $30^{\circ} \mathrm{C}$ for $15 \mathrm{~min}$. Next, $1.0 \mathrm{ml}$ of $0.56 \mathrm{M} \mathrm{HCl}$ was then added, vortexed and centrifuged for $10 \mathrm{~min}$ at $12,000 \mathrm{rpm}$. To $1 \mathrm{ml}$ of the supernatant, $800 \mu \mathrm{l}$ of $0.56 \mathrm{M} \mathrm{HCl}$ and $300 \mu \mathrm{l}$ of 2,4-dinitrophenylhydrazine $(2 \% \mathrm{w} / \mathrm{v})$ were added, vortexed and incubated at $30^{\circ} \mathrm{C}$ for $30 \mathrm{~min}$. Next, $2 \mu \mathrm{l}$ of $2 \mathrm{M} \mathrm{NaOH}$ was added and absorbance was recorded at $540 \mathrm{~nm}$. The ACC deaminase activity was expressed as $\mu \mathrm{mol} / \mathrm{mg}$ protein/h using $\alpha$-ketobutyrate $(0.1$ and $1.0 \mu \mathrm{mol})$ as standard ${ }^{8}$.

The extraction of flavanoid-like compounds was done from the supernatant of $100 \mathrm{ml}$ four-day-old broth 


\section{RESEARCH COMMUNICATIONS}

culture. The supernatant was mixed with $20 \mathrm{ml}$ ethyl acetate and shaken thoroughly for $10-15 \mathrm{~min}$. Then the upper layer of ethyl acetate was separated from each isolate by discarding the lower layer. The extracts were dried at $40^{\circ} \mathrm{C}$ and redissolved in $2 \mathrm{ml}$ of $70 \%$ ethanol. Total flavonoid content was estimated employing the aluminium chloride method proposed by Zhishen et al. ${ }^{9}$, using naringen as standard.

The processing of extracted material was done by thin layer chromatography (TLC) using glass plates $(20 \times$ $15 \mathrm{~cm}$ ) coated with silica gel (GF254). The gel slurry was prepared by dissolving $40 \mathrm{~g}$ silica gel in $100 \mathrm{ml}$ water, followed by activation at $110^{\circ} \mathrm{C}$ for $1 \mathrm{~h}$. The plates were charged with a $50 \mu \mathrm{l}$ aliquot of each sample and developed in solvent-saturated chromatography jars using ethyl acetate: ethanol: water $(5: 1: 5 \mathrm{v} / \mathrm{v} / \mathrm{v})$ solvent mixture. The developed plates were air-dried and visualized under UV light at $365 \mathrm{~nm}$ after the addition of liquid ammonia $^{10}$.

Surface-sterilized chickpea seeds of GPF-2 variety were imbibed in $10 \mathrm{ml}$ of rhizobacterial isolates, alone and in combination with Mesorhizobium ciceri (in $1: 1$ ratio) for $1-2 \mathrm{~h}$. Then they were transferred to sterile petri plates containing double layer of filter paper moistened initially with $4 \mathrm{ml}$ of sterile distilled water, six seeds per plate. The plates were incubated at $22^{\circ} \mathrm{C}$ for nine days. Roots were cut, weighed and ground in a mortar and pestle with $1 \mathrm{ml}$ of $70 \%$ ethanol. Total flavonoid content in the ground material was estimated using the method proposed by Zhishen et al. ${ }^{9}$ and processed by TLC. Other growth parameters such as root and shoot length, root and shoot fresh weight were recorded.

The experiment was conducted during 2013-14 in the Schools of Biotechnology, PAU, Ludhiana, to study the effect of rhizobacteria as seed inoculants, alone and in consortium with $M$. ciceris. Medium black clayey soil from chickpea fields was autoclaved $3 \mathrm{x}\left(1 \mathrm{~h}, 121^{\circ} \mathrm{C}\right)$ at $12 \mathrm{~h}$-intervals and $1 \mathrm{~kg}$ sterilized soil was filled per pot. Surface sterilization of seeds was done with $0.1 \%$ mercuric chloride for $30 \mathrm{sec}$ followed by washing 5-6 times with sterile distilled water and drying under a stream of sterile air. Bacterization of seeds was carried out by imbibing in $10 \mathrm{ml}$ of bacterial inocula $\left(3 \times 10^{8} \mathrm{cfu} \mathrm{ml}^{-1}\right)$ for $3-4 \mathrm{~h}$ with gentle shaking followed by drying. For dual inoculation bacterial and Mesorhizobium inocula were mixed in $1: 1$ ratio. Seeds imbibed in sterile uninoculated media served as control. Ten seeds were sown per pot. The experiment was arranged in a completely randomized design with seven replications per treatment. Growth parameters, including per cent germination, plant height, dry weight, fresh weight and chlorophyll content were recorded.

Antibiotic resistance spectrum of the isolates was studied using filter paper discs containing standard concentration $(\mu \mathrm{g} / \mathrm{disc})$ of antibiotics, viz. ampicillin $\left(\mathrm{AM}^{25}\right)$, chloramphenicol $\left(\mathrm{C}^{25}\right)$, tetracycline $\left(\mathrm{TE}^{30}\right)$, streptomycin
$\left(\mathrm{S}^{10}\right.$ and $\left.\mathrm{S}^{25}\right)$, kanamycin $\left(\mathrm{K}^{5}\right)$, amoxicillin $\left(\mathrm{AMx}^{10}\right)$ and carbenicillin $\left(\mathrm{CB}^{100}\right)$. Antibiotic discs of different concentrations were placed on the lawns of bacteria and incubated at $28^{\circ} \mathrm{C}$ for $72 \mathrm{~h}$. The plates were observed for zone of inhibition around the discs ${ }^{11}$.

Amylase assay was carried out using a reaction mixture consisting of $0.5 \mathrm{ml}$ enzyme extract and $0.5 \mathrm{ml}(1.0 \%)$ soluble starch in $50 \mathrm{mM}$ phosphate buffer ( $\mathrm{pH} 7.0)$, incubated at $30^{\circ} \mathrm{C}$ for $3 \mathrm{~min}$ followed by addition of $1 \mathrm{ml}$ of 3,5-dinitrosalicylic acid to stop the enzymatic reaction. The mixture was then incubated in a boiling water bath for $5 \mathrm{~min}$ and after cooling at room temperature $10 \mathrm{ml}$ distilled water was added and reading of the colour was recorded at $540 \mathrm{~nm}$. One unit (U) of amylase is defined as the amount of enzyme that liberates $1 \mu \mathrm{g}$ of reducing sugars, measured as glucose/min (ref. 12).

Freshly grown bacterial cultures in nutrient broth were diluted to a final optical density of 0.02 (at $600 \mathrm{~nm}$ ) and $150 \mu \mathrm{l}$ of culture was transferred to polystyrene 96 -well microtitre plates. After maintaining for $24 \mathrm{~h} 30^{\circ} \mathrm{C}$, the cultures were removed and microtitre plate wells were gently washed three times with $150 \mu \mathrm{l}$ of sterile water to remove any loosely allied bacteria followed by drying at $30^{\circ} \mathrm{C}$ for $30 \mathrm{~min}$. Samples were stained by adding $1 \%$ crystal violet solution to each well and incubated for $20 \mathrm{~min}$. The vessels were washed and intensity of crystal violet staining was measured by addition of dimethyl sulphoxide to each dry well. The samples were incubated for $20 \mathrm{~min}$ and $\mathrm{OD}_{590}$ values were recorded on a plate reader. All samples were tested in seven independentwells ${ }^{13}$.

Root colonization capability of different strains was studied by inoculating pre-germinated, surface-sterilized chickpea seeds with broth of the respective strains for $30 \mathrm{~min}$. The seeds were then placed in sterilized petri plates containing double layers of moistened filter paper, incubated at $22 \pm 1{ }^{\circ} \mathrm{C}$. After seven days, $0.5 \mathrm{~g}$ root tips were removed, surface sterilized in $0.1 \%$ mercuric chloride and washed with sterile water thrice. It was then shaken vigorously in $9.5 \mathrm{ml}$ of sterile water in an orbital shaking incubator at $100 \mathrm{rpm}$. The bacterial suspension was diluted from $10^{-2}$ to $10^{-5}$, poured into petri plates and incubated at $28^{\circ} \pm 1^{\circ} \mathrm{C}$. The colonies were counted and cfu $\mathrm{ml}^{-1}$ was calculated.

The ability of rhizobacterial isolates to tolerate different salinity levels was examined as described by Zahir et $a l .{ }^{14}$. Bacterial isolates were inoculated in the respective broths at different salinity levels $(0.0,0.2,0.4,0.6$, $0.8,1.0$ and $1.2 \mathrm{M} \mathrm{NaCl}$ ), incubated for $48 \mathrm{~h}$ at $28^{\circ} \pm 1^{\circ} \mathrm{C}$ with shaking at $200 \mathrm{rpm}$, and growth was measured at $600 \mathrm{~nm}$.

Exopolysaccharide (EPS) production was evaluated by the method of De Vuyst et al. ${ }^{15}$. For this, $24 \mathrm{~h}$ old bacterial cultures $\left(\mathrm{OD}_{600} 0.3\right)$ were inoculated in $100 \mathrm{ml}$ of medium described by Verhoef et al. ${ }^{16}$ supplemented with varying $\mathrm{NaCl}$ concentration $(0,0.2,0.4,0.8,1.2 \mathrm{M})$, 
incubated in a $160 \mathrm{rpm}$ shaker for $48 \mathrm{~h}$ at $30^{\circ} \mathrm{C}$, centrifuged under optimized conditions $(1000 \mathrm{rpm}$ for $15 \mathrm{~min}$ at $4^{\circ} \mathrm{C}$ ), and the supernatant was precipitated using three volumes of pre-chilled acetone. Weight of freshly precipitated EPS was recorded.

Experimental data were analysed using standard analysis of variance (ANOVA) followed by post-hoc Duncan's multiple range test (DMRT) to determine the significant difference between groups of data. The results were considered significant at $P \leq 0.05$ level. Standard error was calculated for all mean values.

The rhizo-microbiome discoveries could fuel advances in sustainable agriculture by developing microbial inoculants as biofertilizers, biocontrol or stress protection products ${ }^{17}$. A total of 63 soil-inhabiting bacteria differing in morphological and cultural characteristics were isolated from different chickpea rhizospheres; 35 were picked from King's B medium while 28 from nutrient agar medium.

All the isolates were tested for their plant growthpromoting traits to select the candidates having potential to emerge as bioinoculant. The tri-calcium phosphate solubilizing ability was revealed by 15 isolates on NBRIP medium, which ranged from 1.14 to 2.3 (Table 1). Although the isolate Ps19d did not exhibit P-solubilization activity on NBRIP medium, it solubilized phosphate on Pikovskaya medium in another set of experiments conducted by Kumari et al. ${ }^{18}$. This indicates that the visible halo/zone formation on agar plates due to the production of organic acids as the criterion for isolation of phosphate solubilizers is a less reliable approach, and more efficient results could be drawn from broth-based assay. A similar experiment conducted for selecting $\mathrm{Zn}$ solubilizing bacteria revealed that 20 isolates were able to solubilize $\mathrm{ZnO}$, including Ps14d and Ps14c which were efficient P-solubilizers. In the soil, both macro- and micronutrients undergo a complex dynamic equilibrium of solubilization and insolubilization that is greatly influenced by soil $\mathrm{pH}$ and microflora, ultimately affecting their accessibility to plants ${ }^{19}$. A search for microorganisms with dual ability to solubilize micro- and macronutrients could proficiently enhance plant growth by reducing the load of chemical fertilizers. The importance of insoluble P-solubilizing microbial strains in vitro for managing nutrient requirements of plants has been demonstrated by Suseelendra et al. ${ }^{20}$.

Evaluating the rhizobacterial isolates for their ability to produce IAA, it was observed that all isolates tested positive for IAA synthesis. Nevertheless, presence of Trp greatly affected IAA production; although it is considered to be strain-dependent ${ }^{1}$. In the absence of Trp, IAA production ranged from 1.78 to $39.02 \mu \mathrm{g} / \mathrm{ml}$ which increased to $9.96-45.7 \mu \mathrm{g} / \mathrm{ml}$ in the presence of $3 \mathrm{mM}$ Trp (Table 1). This is likely to be associated with biosynthesis of IAA using Trp as precursor as the most common pathway. The correlation of IAA biosynthesis by rhizobacteria with stimulation of root proliferation is well documented $^{21}$, as it increases the ability of young seedlings to anchor themselves to the soil, and obtain water and nutrients from their environment, thus enhancing their chances for survival ${ }^{22}$. Apart from IAA production, the beneficial effect of PGPR on growth and yield of many crop plants can likely be highlighted, at least in part, by gibberellin production ${ }^{23}$. The gibberellin production by 29 rhizobacterial isolates ranged from 11.90 to $30.70 \mu \mathrm{g} / \mathrm{ml}$, the highest being observed with isolates Ps $14 \mathrm{c}$ and B-I (25.30 and $24.89 \mu \mathrm{g} / \mathrm{ml}$ respectively; Table 1). Probanza et al. ${ }^{24}$ reported that inoculation with Bacillus licheniformis and Bacillus pumilus improved growth of Pinus pinea plants, apparently through production of bacterial gibberellins.

The rhizobacteria also have immense potential to enhance plant growth under stress conditions by altering the synthesis of stress-induced ethylene through the production of enzyme ACC deaminase. The search for ACCdeaminase producing bacteria revealed that the isolates were able to use ACC deaminase as the sole source of nitrogen. Biochemical assay for ACC deaminase showed that isolates Ps14c, B20b and B-I (4.61, 2.56 and $1.41 \mu \mathrm{M} \alpha$-ketobutyrate/mg protein/h respectively) were the strongest producers (Table 1). In corroboration with the present findings, Ali et al. ${ }^{25}$ reported ACC deaminase production by nine isolates of drought-tolerant Pseudomonas fluorescens, maximum being observed with strain SogrP4 (3.71 $\mu \mathrm{M} \quad \alpha$-ketobutyrate/mg protein $/ \mathrm{h}) . \quad$ ACC deaminase-containing bacteria reduce the need of plants to actively protect themselves against various environmental stresses by upregulating the genes involved in plant growth and protein production while downregulating those involved with ethylene stress and defence signalling pathways ${ }^{26}$.

The role of flavonoids in the nitrogen-fixing symbiosis between legumes and rhizobia as plant chemotactic signals to rhizobia and as activators of nod gene expression is well documented ${ }^{27}$. Flavonoids exuded through the plant roots interact with the product of rhizobial nodD gene, which then colonizes the soil in the vicinity of the root hair ${ }^{28}$. In the present study, evaluation of PGPR for the production of flavonoid-like compounds revealed a great variation in the range, viz. $25.55-85.77 \mu \mathrm{g} / 100 \mathrm{ml}$ (Table 1). Reportedly, bacteria, especially Pseudomonas and Bacillus associated with the rhizosphere of various leguminous crops, may assist rhizobia in root colonization by producing compounds similar to that of flavono$\operatorname{ids}^{10}$. To ascertain compounds in the culture media, ethyl acetate extracts of broth culture supernatant fluids of different isolates were processed by TLC using naringin (flavanone glycoside) as a standard. Under UV transillumination, the TLC plates showed a single fluorescent pigment in culture supernatants of isolates B-20d and B-I having similar mobility as that of naringin, while culture supernatant of isolate Ps14c showed two fluorescent 
RESEARCH COMMUNICATIONS

\begin{tabular}{|c|c|c|c|c|c|c|c|}
\hline \multirow[b]{2}{*}{ Isolates } & \multirow{2}{*}{$\begin{array}{c}\text { P-solubilization } \\
\text { index }\end{array}$} & \multirow{2}{*}{$\begin{array}{l}\text { Zn-solubilization } \\
\text { index }\end{array}$} & \multicolumn{2}{|c|}{ IAA production $(\mu \mathrm{g} / \mathrm{ml})$} & \multirow{2}{*}{$\begin{array}{c}\text { Gibberellic acid } \\
\text { production } \\
(\mu \mathrm{g} / 25 \mathrm{ml})\end{array}$} & \multirow{2}{*}{$\begin{array}{c}\text { ACC-d activity } \\
\text { ( } \mu \mathrm{M} \alpha \text {-ketobutyrate/ } \\
\mathrm{mg} / \mathrm{h})\end{array}$} & \multirow{2}{*}{$\begin{array}{l}\text { Flavonoids } \\
\text { production } \\
(\mu \mathrm{g} / 100 \mathrm{ml})\end{array}$} \\
\hline & & & No tryptophan & $3 \mathrm{mM}$ tryptophan & & & \\
\hline Ps $13 b$ & - & - & $13.07 \pm 1.04$ & $12.84 \pm 0.25$ & $14.38 \pm 1.28$ & $0.76 \pm 0.02$ & - \\
\hline Ps $14 \mathrm{c}$ & $1.71 \pm 0.06$ & $1.52 \pm 0.12$ & $7.61 \pm 0.28$ & $24.86 \pm 2.15$ & $25.30 \pm 2.21$ & $4.61 \pm 0.12$ & $85.77 \pm 6.10$ \\
\hline Ps $15 \mathrm{a}$ & $1.14 \pm 0.08$ & $1.27 \pm 0.07$ & $21.18 \pm 0.10$ & $25.31 \pm 1.17$ & $18.80 \pm 1.11$ & - & - \\
\hline Ps19d & - & $1.77 \pm 0.15$ & $1.78 \pm 0.18$ & $20.42 \pm 0.24$ & $20.60 \pm 1.17$ & - & - \\
\hline B17b & - & - & $39.02 \pm 1.11$ & $42.77 \pm 3.29$ & $15.14 \pm 0.28$ & - & - \\
\hline $\mathrm{B} 20 \mathrm{~b}$ & $1.20 \pm 0.11$ & $1.14 \pm 0.08$ & $3.94 \pm 0.08$ & $45.70 \pm 3.28$ & $15.80 \pm 1.08$ & $2.56 \pm 0.08$ & $25.55 \pm 2.14$ \\
\hline B20d & $1.14 \pm 0.02$ & - & $2.16 \pm 0.09$ & $29.93 \pm 2.07$ & $21.32 \pm 2.11$ & $1.36 \pm 0.11$ & $52.92 \pm 4.07$ \\
\hline $\mathrm{B} 28 \mathrm{c}$ & - & $1.23 \pm 0.03$ & $8.18 \pm 0.10$ & $19.62 \pm 1.07$ & $24.85 \pm 1.18$ & $1.04 \pm 0.09$ & $34.67 \pm 3.09$ \\
\hline B-I & $1.55 \pm 0.02$ & - & $14.58 \pm 0.28$ & $30.50 \pm 1.28$ & $24.89 \pm 2.17$ & $2.42 \pm 0.04$ & $54.75 \pm 3.20$ \\
\hline
\end{tabular}

Values represent mean \pm SE of three replications. IAA, Indole-3-acetic acid; ACC-d, 1-aminocyclo propane-1-carboxylic acid-deaminase.

Table 2. Effect of seed bacterization on induction of flavonoids from roots and growth parameters of chickpea under axenic condition

\begin{tabular}{|c|c|c|c|c|c|}
\hline \multirow[b]{2}{*}{ Treatment } & \multirow[b]{2}{*}{ Flavanoids (mg/gfw) } & \multicolumn{2}{|c|}{ Fresh weight (mg/plant) } & \multicolumn{2}{|c|}{ Length $(\mathrm{cm} /$ plant } \\
\hline & & Root & Shoot & Root & Shoot \\
\hline Ps $14 \mathrm{c}$ & $54.64^{\mathrm{b}}$ & $61.17^{\mathrm{bc}}$ & $10.01^{\mathrm{c}}$ & 5.18 & $1.00^{\mathrm{fg}}$ \\
\hline Ps14c+R & $76.78^{\mathrm{a}}$ & $71.13^{\mathrm{a}}$ & $16.90^{\mathrm{a}}$ & 5.37 & $3.12^{\mathrm{a}}$ \\
\hline B20d & $51.07^{\mathrm{cd}}$ & $55.00^{\mathrm{d}}$ & $8.50^{\mathrm{c}}$ & 6.67 & $1.00^{\mathrm{f}}$ \\
\hline $\mathrm{B} 20 \mathrm{~d}+\mathrm{R}$ & $62.14^{\mathrm{b}}$ & $68.75^{\mathrm{ab}}$ & $8.84^{\mathrm{c}}$ & 6.79 & $1.25^{\mathrm{ef}}$ \\
\hline $\mathrm{B} 20 \mathrm{~b}$ & $55.35^{\mathrm{b}}$ & $63.33^{\mathrm{abc}}$ & $9.45^{\mathrm{c}}$ & 4.24 & $1.00^{\mathrm{eg}}$ \\
\hline $\mathrm{B} 20 \mathrm{~b}+\mathrm{R}$ & $58.90^{\mathrm{bc}}$ & $65.83^{\mathrm{abc}}$ & $13.66^{\mathrm{ab}}$ & 4.79 & $1.94^{\mathrm{d}}$ \\
\hline B-I & $53.92^{\mathrm{bcd}}$ & $60.41^{\mathrm{c}}$ & $9.10^{\mathrm{c}}$ & 5.15 & $1.95^{\mathrm{d}}$ \\
\hline B - I + R & $73.57^{\mathrm{a}}$ & $68.16^{\mathrm{ac}}$ & $16.94^{\mathrm{a}}$ & 6.13 & $2.30^{\text {cd }}$ \\
\hline $\mathrm{B} 28 \mathrm{c}$ & $60.35^{\mathrm{b}}$ & $62.91^{\mathrm{bc}}$ & $13.00^{\mathrm{b}}$ & 4.33 & $1.50^{\mathrm{e}}$ \\
\hline $\mathrm{B} 28 \mathrm{c}+\mathrm{R}$ & $58.21^{\mathrm{bc}}$ & $64.16^{\mathrm{abc}}$ & $16.45^{\mathrm{a}}$ & 4.62 & $2.50^{\mathrm{b}}$ \\
\hline Control & $45.71^{\mathrm{d}}$ & $50.83^{\mathrm{d}}$ & $7.90^{\mathrm{c}}$ & 4.06 & $0.80^{\mathrm{g}}$ \\
\hline CD@5\% & 8.35 & 8.13 & 3.42 & NS & 0.37 \\
\hline
\end{tabular}

In the same column, significant differences at $P<0.05$ levels are indicated by different letters. Data followed by the same letter in the same column are not significantly different from each other according to analysis of variance (ANOVA).

compounds, one with higher mobility and other similar to naringin. However, isolate B-20b exhibited one fluorescent spot of lower mobility, whereas none was observed with B28c. Similar findings have been reported by Parmar and Dadarwal ${ }^{10}$, where the TLC plates showed no fluorescent pigment in culture supernatant of Bacillus CRS70, whereas culture supernatant of Pseudomonas sp. CRP55b showed two fluorescent compounds with relative mobility in the solvent system used. The production of flavonoid-like compounds by rhizobacterial isolates confirms their role in enhanced nodulation through better rhizobial colonization and plant growth promotion assisted by phytohormones production and improved nutrient uptake. Andrade et al. ${ }^{29}$ reported that an increase in nodulation in pea caused by inoculation with P. fluorescens was due to an increase in flavonoid exudation by the host plant.

The effect of seed bacterization on flavonoid exudation from plant roots under axenic condition showed higher accumulation of flavonoids in the roots in response to bacterial inoculation compared to uninoculated control (Table 2). Co-inoculation of isolates Ps-14c and B-I with Mesorhizobium recorded the highest flavonoid content in the roots ( 76.78 and $73.57 \mathrm{mg} / \mathrm{g}$ fresh wt respectively). It has been reported that rhizobacteria induce phytoalexins (a class of fluorescent compounds, closely related to flavonoids and isoflavonoids) in the roots of several crop plants $^{30}$ which results in antibiosis in the rhizosphere for pathogenic organisms and thus increases nodulation by providing better environment for rhizobial colonization. Processing of root extracts by TLC revealed a single fluorescent compound with higher mobility compared to fluorescent pigments observed with the supernatant extract of bacterial isolates. In contrast, Parmar and Dadarwal $^{10}$ reported three different compounds in the root extract of plants inoculated with Pseudomonas, whereas two spots in Bacillus-inoculated extracts. Moreover, seed bacterization resulted in higher root fresh weight, shoot fresh weight, root and shoot length compared to uninoculated control (Table 2). 
RESEARCH COMMUNICATIONS

Table 3. Effect of seed bacterization on growth parameters of chickpea under glasshouse condition

\begin{tabular}{|c|c|c|c|c|c|}
\hline Treatment & $\%$ Germination & Plant height $(\mathrm{cm})$ & Plant fresh weight $(\mathrm{g})$ & Plant dry weight (g) & Chlorophyll content $(\mathrm{mg} / \mathrm{g})$ \\
\hline $\mathrm{B}-\mathrm{I}+\mathrm{R}$ & 95 & $23.30^{\mathrm{a}}$ & $9.3^{\mathrm{a}}$ & 2.06 & $0.94^{\mathrm{a}}$ \\
\hline Ps $14 c+R$ & 95 & $22.62^{\mathrm{ab}}$ & $8.7^{\mathrm{ab}}$ & 1.80 & $0.85^{\mathrm{a}}$ \\
\hline B-I & 94 & $22.55^{\mathrm{ab}}$ & $9.1^{\mathrm{a}}$ & 1.91 & $0.96^{\mathrm{a}}$ \\
\hline Ps $14 \mathrm{c}$ & 93 & $21.35^{\mathrm{ab}}$ & $8.1^{\mathrm{ab}}$ & 1.60 & $0.75^{\mathrm{ab}}$ \\
\hline Control & 90 & $19.11^{\mathrm{b}}$ & $6.6^{\mathrm{b}}$ & 1.20 & $0.61^{\mathrm{b}}$ \\
\hline $\mathrm{CD} @ 5 \%$ & & 4.10 & 2.12 & NS & 0.21 \\
\hline
\end{tabular}

In the same column, significant differences at $P<0.05$ levels are indicated by different letters. Data followed by the same letter in the same column are not significantly different from each other according to ANOVA.

Table 4. Intrinsic antibiotic resistance spectra of rhizobacterial isolates

\begin{tabular}{lccccccc}
\hline Isolates & $\begin{array}{c}\text { Ampicillin } \\
(25 \mathrm{mcg})\end{array}$ & $\begin{array}{c}\text { Tetracycline } \\
(30 \mathrm{mcg})\end{array}$ & $\begin{array}{c}\text { Streptomycin } \\
(10 \mathrm{mcg})\end{array}$ & $\begin{array}{c}\text { Chloramphenicol } \\
(25 \mathrm{mcg})\end{array}$ & $\begin{array}{c}\text { Kanamycin } \\
(5 \mathrm{mcg})\end{array}$ & $\begin{array}{c}\text { Amoxicillin } \\
(10 \mathrm{mcg})\end{array}$ & $\begin{array}{c}\text { Carbenicillin } \\
(100 \mathrm{mcg})\end{array}$ \\
\hline Ps14c & $\mathrm{R}$ & $\mathrm{S}(+)$ & $\mathrm{S}(+++)$ & $\mathrm{S}(++)$ & $\mathrm{S}(+++)$ & $\mathrm{S}(+)$ & $\mathrm{S}(+)$ \\
$\mathrm{B} 20 \mathrm{~d}$ & $\mathrm{R}$ & $\mathrm{S}(+)$ & $\mathrm{S}(+++)$ & $\mathrm{S}(++)$ & $\mathrm{S}(++)$ & $\mathrm{S}(+)$ & $\mathrm{S}(+)$ \\
$\mathrm{B} 20 \mathrm{~b}$ & $\mathrm{R}$ & $\mathrm{S}(+)$ & $\mathrm{S}(++)$ & $\mathrm{S}(++)$ & $\mathrm{S}(++)$ & $\mathrm{S}(+)$ & $\mathrm{S}(+)$ \\
B28c & $\mathrm{R}$ & $\mathrm{R}$ & $\mathrm{S}(++)$ & $\mathrm{S}(++)$ & $\mathrm{S}(++)$ & $\mathrm{S}(+)$ & $\mathrm{S}(+)$ \\
B-I & $\mathrm{R}$ & $\mathrm{R}$ & $\mathrm{S}(+)$ & $\mathrm{R}$ & $\mathrm{S}(+++)$ & $\mathrm{S}(+)$ & $\mathrm{S}(+)$ \\
\hline
\end{tabular}

R, Resistant; S, Sensitive; +, Least sensitive; ++ , Moderately sensitive and +++ , Highly sensitive.

Based on in vitro assayed plant growth-promoting traits, isolates Ps-14c and B-I were used as single as well as co-inoculants with chickpea-nodulating $M$. ciceri to determine their plant growth-promoting effect under glasshouse condition. The isolates significantly enhanced plant biomass, plant height and chlorophyll content in inoculated plants compared to uninoculated control (Table 3). However, isolate B-I was the most effective in terms of shoot weight and chlorophyll content compared to Ps-14c. In the co-inoculation experiment, further increase in plant height, plant weight and chlorophyll content in plants was observed (Table 3 ), which signifies secretion of some plant growth-promoting hormones such as IAA, gibberellins, etc. by Rhizobium leading to synergism between the two isolates. There are reports on the production of plant growth regulators like auxins, cytokinins and gibberellins by rhizobia that stimulate and enhance plant growth ${ }^{31}$. Moreover, synergism could also be attributed to the flavonoid-like compounds produced by rhizobacteria, which assist in better colonization of rhizobia.

The replication of successful soil microcosm results of PGPR under field conditions has been reported to be limited by the environment that does not support growth and survival of the introduced microorganisms in the plant rhizosphere ${ }^{32}$. Manipulating soil environment to make it better for bacterial survival is not feasible, but understanding the mechanisms that assist in their subsistence under stress condition would be the key to improving the level and reliability of plant growth stimulation by PGPR. Therefore, we focused on characterizing potent PGPR (Ps14c, B20d, B-20b, B-I and B-28c) for determinants related to their survival and colonization in the rhizo-microbiome that would possibly aid in developing efficient biofertilizer inoculants under field condition.

The intrinsic antibiotic resistance spectra of rhizobacteria offer an ecological advantage of survival in the rhizosphere when they are introduced as incoulum ${ }^{33}$. Most of the isolates were resistant to ampicillin and sensitive to chloramphenicol, streptomycin and erythromycin (Table 4). However, isolate B-I showed intrinsic resistance to ampicillin, tetracycline and chloramphenicol and exhibited less sensitivity to streptomycin, kanamycin, amoxicillin and carbenicillin, which is a desirable feature for developing efficient microbial inoculants.

The survival of organisms in a new environment depends on their ability to utilize the source of nutrients available at a particular site. In this regard, amylase has importance as starch is widely distributed in nature and the enzyme can assist in the easy survival of microorganisms by mediating hydrolysis of starch or any other readily available related $\alpha$-glucan elsewhere ${ }^{34}$. In the present study, all the five potent isolates produced amylase, the maximum by B20d $(38.7 \mathrm{U} / \mathrm{ml} / \mathrm{min})$ followed by Ps $14 \mathrm{c}$ (35.7 U/ml/min; Table 5). Amylase has also been reported to affect the cell wall of some phytopathogenic fungi where glycogen, a polysaccharide closely related to starch, is present. It is unlikely that this enzyme plays a key role in the early phase of antagonistic association ${ }^{35}$.

Biofilms are bacterial communities in which the cells are embedded in a matrix of extracellular polymeric compounds attached to the surface, which protects them from deleterious conditions ${ }^{36}$. Biofilm formation assayed by crystal violet staining was evident for rhizobacterial isolate B-20d followed by Ps-14c and B20b (ref. 37; Table 5). The dense biofilm matrix limits diffusion of 


\section{RESEARCH COMMUNICATIONS}

Table 5. Competence-related determinants of potent rhizobacterial isolates

\begin{tabular}{|c|c|c|c|c|c|c|c|c|c|c|c|c|c|}
\hline \multirow[b]{2}{*}{ Isolates } & \multirow{2}{*}{$\begin{array}{c}\text { Amylase } \\
\text { activity } \\
(\mathrm{U} / \mathrm{ml} / \mathrm{min})\end{array}$} & \multirow{2}{*}{$\begin{array}{l}\text { Biofilm } \\
\text { formation } \\
\left(\mathrm{OD}_{590}\right)\end{array}$} & \multicolumn{5}{|c|}{$\begin{array}{l}\text { Growth under varying } \mathrm{NaCl} \\
\text { concentration }\left(\mathrm{OD}_{600}\right)\end{array}$} & \multicolumn{6}{|c|}{$\begin{array}{l}\text { Exopolysaccharide production at different } \\
\text { salinity levels (fresh weight in g) }\end{array}$} \\
\hline & & & $0.5 \mathrm{M}$ & $1.0 \mathrm{M}$ & $1.5 \mathrm{M}$ & $2.0 \mathrm{M}$ & $2.5 \mathrm{M}$ & $0 \mathrm{M}$ & $0.2 \mathrm{M}$ & $0.4 \mathrm{M}$ & $0.8 \mathrm{M}$ & $1.0 \mathrm{M}$ & $1.2 \mathrm{M}$ \\
\hline Ps $14 \mathrm{c}$ & $35.70 \pm 3.11$ & $0.111 \pm 0.009$ & $\begin{array}{l}0.115 \pm \\
0.02\end{array}$ & $\begin{array}{c}0.085 \pm \\
0.004\end{array}$ & $\begin{array}{c}0.015 \pm \\
0.00\end{array}$ & $\begin{array}{c}0.00 \pm \\
0.00\end{array}$ & $\begin{array}{c}0.00 \pm \\
0.00\end{array}$ & - & - & - & - & - & - \\
\hline B20d & $38.70 \pm 4.29$ & $0.353 \pm 0.016$ & $\begin{array}{c}0.892 \pm \\
0.09\end{array}$ & $\begin{array}{l}0.784 \pm \\
0.09\end{array}$ & $\begin{array}{c}0.539 \pm \\
0.05\end{array}$ & $\begin{array}{l}0.192 \pm \\
0.01\end{array}$ & $\begin{array}{c}0.085 \pm \\
0.01\end{array}$ & $\begin{array}{c}0.13 \pm \\
0.02\end{array}$ & $\begin{array}{c}0.12 \pm \\
0.01\end{array}$ & $\begin{array}{c}0.17 \pm \\
0.03\end{array}$ & $\begin{array}{c}0.22 \pm \\
0.06\end{array}$ & $\begin{array}{c}0.13 \pm \\
0.02\end{array}$ & $\begin{array}{c}0.12 \pm \\
0.02\end{array}$ \\
\hline $\mathrm{B} 20 \mathrm{~b}$ & $17.50 \pm 2.96$ & $0.078 \pm 0.001$ & $\begin{array}{c}0.780 \pm \\
0.07\end{array}$ & $\begin{array}{c}0.669 \pm \\
0.08\end{array}$ & $\begin{array}{c}0.493 \pm \\
0.04\end{array}$ & $\begin{array}{c}0.115 \pm \\
0.01\end{array}$ & $\begin{array}{c}0.082 \pm \\
0.01\end{array}$ & $\begin{array}{c}0.16 \pm \\
0.01\end{array}$ & $\begin{array}{c}0.18 \pm \\
0.02\end{array}$ & $\begin{array}{c}0.19 \pm \\
0.04\end{array}$ & $\begin{array}{c}0.18 \pm \\
0.04\end{array}$ & $\begin{array}{c}0.31 \pm \\
0.08\end{array}$ & $\begin{array}{c}0.10 \pm \\
0.01\end{array}$ \\
\hline B28c & $19.00 \pm 2.87$ & $0.101 \pm 0.008$ & $\begin{array}{c}0.65 \pm \\
0.07\end{array}$ & $\begin{array}{c}0.480 \pm \\
0.01\end{array}$ & $\begin{array}{c}0.296 \pm \\
0.02\end{array}$ & $\begin{array}{c}0.061 \pm \\
0.00\end{array}$ & $\begin{array}{c}0.00 \pm \\
0.00\end{array}$ & - & - & - & - & - & - \\
\hline B-I & $19.70 \pm 3.01$ & $0.073 \pm 0.003$ & $\begin{array}{c}0.770 \pm \\
0.08\end{array}$ & $\begin{array}{c}0.568 \pm \\
0.02\end{array}$ & $\begin{array}{c}0.346 \pm \\
0.03\end{array}$ & $\begin{array}{c}0.105 \pm \\
0.01\end{array}$ & $\begin{array}{c}0.024 \pm \\
0.02\end{array}$ & $\begin{array}{c}0.16 \pm \\
0.01\end{array}$ & $\begin{array}{c}0.14 \pm \\
0.01\end{array}$ & $\begin{array}{c}0.15 \pm \\
0.03\end{array}$ & $\begin{array}{c}0.21 \pm \\
0.06\end{array}$ & $\begin{array}{c}0.35 \pm \\
0.10\end{array}$ & $\begin{array}{c}0.28 \pm \\
0.07\end{array}$ \\
\hline
\end{tabular}

Values represent mean $\pm \mathrm{SE}$ of three replications.

bioactive substances and nutritional elements secreted by root bacteria which remain concentrated at the root surface and directly affect plant growth. It has been reported that plant roots are not passive targets for bacteria and inability of PGPR to act as efficient bioinoculants under field condition has often been related to their lack of capability to colonize plant roots. However, biofilm formation could faithfully reflect bacterial colonization. Likewise, the results of viable counts of bacteria from infected chickpea roots indicated rapid colonization by B20b $\left(190 \times 10^{6} \mathrm{cfu} / \mathrm{g}\right)$ followed by B20d $(119 \times$ $\left.10^{6} \mathrm{cfu} / \mathrm{g}\right)$, B-I $\left(37 \times 10^{6} \mathrm{cfu} / \mathrm{g}\right)$, Ps $14 \mathrm{c}\left(90 \times 10^{5} \mathrm{cfu} / \mathrm{g}\right)$ and B28c $\left(67 \times 10^{5} \mathrm{cfu} / \mathrm{g}\right)$. Efficient colonizers can be developed after inoculating seedlings with a combination of different bacteria, followed by growth of the seedlings in a gnotobiotics system ${ }^{38}$.

Screening for osmoadaptation revealed that isolates B20d, B20b and B-I were able to tolerate up to $2.5 \mathrm{M}$ salinity level, whereas B28c was relatively less tolerant (Table 5). Isolate Ps-14c which surpassed in all growthpromoting traits was quite sensitive to salinity even at $0.5 \mathrm{M}$ level $\left(\mathrm{OD}_{600} 0.155\right)$. Salt-tolerant characteristics of PGPR reflect their ability to adapt and persist under stressed environment ${ }^{39}$. Paul and Nair ${ }^{39}$ reported that the root colonization ability of the salt-tolerant Pseudomonas strain was not hindered even at higher salinity levels in the soil.

Bacterial EPS plays a crucial role in auto-aggregation, biofilm development and protection against salinity stress. The study of EPS production at different salinity levels by osmotolerant isolates revealed increasing trend in fresh weight of EPS (Table 5), thus implicating the possible role of biofilm and EPS production for effective colonization under adverse conditions. The EPS improved soil aggregation, water stability and microbial biomass stimulated root exudation under stress ${ }^{40}$.

The screening strategies used in the present study could provide valuable strains with multiple plant growth-promoting traits that are rhizospheric competent and can establish successfully in the introduced environment. This would possibly help in combating the differences observed in the performance of efficient strains under field conditions.

1. Ahmad, F. I., Ahmad, I. and Khan, M. S., Screening of free-living rhizospheric bacteria for their multiple plant growth promoting activities. Microbiol. Res., 2008, 163, 173-181.

2. Lutenberg, B. and Kamivola, F., Plant-growth-promoting rhizobacteria. Annu. Rev. Microbiol., 2009, 63, 541-546.

3. Vessey, J. K., Plant growth promoting rhizobacteria as biofertilizers. Plant Soil, 2003, 255, 571-586.

4. Bent, E., Tuzun, S., Chanway, C. P. and Enebak, S., Alterations in plant growth and in root hormone levels of lodgepole pines inoculated with rhizobacteria. Can. J. Microbiol., 2001, 47, 793-800.

5. Nautiyal, C. S., An efficient microbiological growth medium for screening phosphate solubilizing microorganisms. FEMS Microbiol. Lett., 1999, 170, 265-270.

6. Gordon, A. S. and Weber, R. P., Calorimetric estimation of indole acetic acid. Plant Physiol., 1951, 25, 192-195.

7. Borrow, A. et al., Gibberellic acid, a metabolic product of the fungus Gibberella fujikuroi: some observations on its production and isolation. J. Sci. Food. Agric., 1955, 6, 340-348.

8. Penrose, D. M. and Glick, B. R., Methods for isolating and characterizing ACC deaminase-containing plant growth-promoting rhizobacteria. Physiol. Planta, 2003, 1, 10-15.

9. Zhishen, J., Mengcheng, T. and Jianming, W., The determination of flavonoid contents in mulberry and their scavenging effects on superoxide radicals. Food Chem., 1999, 64, 555-559.

10. Parmar, N. and Dadarwal, K. R., Stimulation of nitrogen fixation and induction of flavonoid like compounds by rhizobacteria. J. Appl. Microbiol., 1999, 86, 36-44.

11. Bauer, A. W., Kirby, W. M., Sherris, J. C. and Turck, M., Antibiotic susceptibility testing by a standardized single disk method. Am. J. Clin. Pathol., 1996, 45, 493-496.

12. Bernfeld, P., Enzymes of starch degradation and synthesis. $A d v$. Enzymol., 1951, 12, 379-481.

13. Haggag, W. M. and Timmusk, S., Colonization of peanut roots by biofilm forming Paenibacillus polymyxa initiates biocontrol against crown rot disease. J. Appl. Microbiol., 2008, 104, 961969.

14. Zahir, Z. A., Shah, M. K., Naveed, M. and Akhter, M. J., Substrate dependent auxin production by Rhizobium phaseoli improves the growth and yield of Vigna radiata L. under salt stress conditions. J. Microbiol. Biotechnol., 2010, 20, 1288-1294. 
15. De Vuyst, L., Vanderveken, F., Van de ven, S. and Degeest, B., Production by and isolation of exopolysaccharides from Streptococcus thermophilus grown in milk medium and evidence for their growth associated biosynthesis. J. Appl. Microbiol., 1998, 8, 1059-1068.

16. Verhoef, R., Waard, P. D., Schols, H. A., Siika-aho, M. and Voragen, A. G. J., Methylobacterium sp. isolated from a Finnish paper machine produces highly pyruvate galactan exopolysaccharide. Carbohydr. Res., 2003, 338, 1851-1859.

17. Berg, G., Zachow, C., Lottmann, J., Gotz, M., Costa, R. and Smalla, K., Impact of plant species and site on rhizosphereassociated fungi antagonistic to Verticillium dahlia Kleb. Appl. Environ. Microbiol., 2009, 71, 4203-4213.

18. Kumari, P., Khanna, V. and Kumar, P., Multifaceted rhizobacteria mediated growth augmentation in chickpea. Agric. Res., 2017; doi:10.1007/s40003-017-0275-5.

19. Altomare, C., Norvell, W. A., Bjorkma, T. and Harman, G. E., Solubilization of phosphates and micronutrients by the plantgrowth-promoting and biocontrol fungus Trichoderma harzianum. Appl. Environ. Microbiol., 1999, 65, 2926-2933.

20. Suseelendra, D., Parveen, K. G., Uzma, S., Sravani, P., Mir, H. A. S. K., Leo, D. A. E. and Gopal, R., Potential microbial candiadate strains for management of nutrient requirements of crops. Afr. J. Microbiol. Res., 2012, 6, 3924-3931.

21. Spaepen, S., Vanderleyden, J. and Remans, R., Indole-3-acetic acid in microbial and microorganism-plant signaling. FEMS Microbiol. Rev., 2007, 31, 425-448.

22. Patten, C. L. and Glick, B. R., Role of Pseudomonas putida indole acetic acid in development of the host plant root system. Appl. Environ. Microbiol., 2002, 68, 3795-3801.

23. Bottini, R., Cassán, F. and Piccoli, P., Gibberellin production by bacteria and its involvement in plant growth promotion and yield increase. Appl. Microbiol. Biotechnol., 2004, 65, 497-503.

24. Probanza, A., García, J. A. L., Palomino, M. R., Ramos, B. and Manero, F. J. G., Pinus pinea L. seedling growth and bacterial rhizosphere structure after inoculation with PGPR Bacillus (B. licheniformis CECT 5106 and B. pumilus CECT 5105). Appl. Soil. Ecol. 2002, 20, 75-84.

25. Ali, S. Z., Sadhya, V. and Rao, L. V., Isolation and characterization of drought-tolerant ACC deaminase and exopolysaccharide-producing fluorescent Pseudomonas sp. Ann. Microbiol., 2013, 64, 492-502.

26. Hontzeas, N., Richardson, A. O., Belimov, A., Safronova, V., Abu-Omar, M. M. and Glick, B. R., Evidence for horizontal transfer of 1-aminocyclopropane-1-carboxylate deaminase genes. Appl. Environ. Microbiol., 2005, 71, 7556-7558.

27. Oldroyd, G. E. and Downie, J. A., Coordinating nodule morphogenesis with rhizobial infection in legumes. Annu. Rev. Plant. Biol., 2008, 59, 519-546.

28. Russelle, M. P., Biological dinitrogen fixation in agriculture. In Nitrogen in Agricultural Systems (eds Schepers, J. S. and Raun, W. R.), Agronomy Monograph, 2008, 2nd edn, pp. 281-359.

29. Andrade, G., Deleij, F. A. and Lynch, J. M., Plant mediated interactions between Pseudomonas fluorescens, Rhizobium leguminosarum and arbuscular mycorrhizae on pea. Lett. Appl. Microbiol., 1998, 26, 311-316.

30. Van peer, R., Niemann, G. J. and Schippers, B., Induced resistance and phytoalexin accumulation in biological control of Fusarium wilt of carnation of Pseudomonas sp. WCS417r. Phytopathology, 1991, 81, 726-730.

31. Hemissi, I., Mabrouk, Y., Abdi, N., Bouraoui, M., Saidi, M. and Sifi, B., Effects of some Rhizobium strains on chickpea growth and biological control of Rhizoctonia solani. Afr. J. Microbiol. Res., 2011, 5, 4080-4090.

32. Martínez-Viveros, O., Jorquera, M. A., Crowley, D. E., Gajardo, G. and Mora, M. L., Mechanisms and practical considerations involved in plant growth promotion by rhizobacteria. J. Soil Sci. Plant. Nutr., 2010, 10, 293-319.
33. Yasmin, F., Othman, R., Sijam, K. and Saad, M. S., Characterization of beneficial properties of plant growth promoting rhizobacteria isolated from sweet potato rhizosphere. Afr. J. Microbiol. Res., 2009, 3, 815-821.

34. Marco, J. S. D., Inglis, M. C. V. and Felix, C. R., Production of hydrolytic enzymes by Trichoderma isolates with antagonistic activity against Crinipellis pereniciosa, the causal agent of whitches broom of cocoa. Braz. J. Microbiol., 2003, 34, 33-38.

35. Azevedo, A. M. C., De Marco, J. L. and Felix, C. R., Characterization of an amylase produced by a Trichoderma harzianum isolate with antagonistic activity against Crinipellis perniciosa, the causal agent of witches' broom of cocoa. FEMS Microbiol. Lett., 2000, 188, 171-175.

36. Davey, M. E. and O'Toole, G. A., Microbial biofilms: from ecology to molecular genetics. Microbiol. Mol. Biol. Rev., 2000, 64, $847-867$.

37. Friedman, L. and Kolter, R., Genes involved in matrix formation in Pseudomonas aeruginosa PA14 biofilms. Mol. Microbiol., 2004, 51, 675-690.

38. Simons, M., van der Bij, A. J., Brand, I., de Weger, L. A., Wijffelman, C. A. and Lugtenberg, B. J. J., Gnotobiotic system for studying rhizosphere colonization by plant growth-promoting Pseudomonas bacteria. Mol. Plant-Microbe. Interact., 1996, 9, 600-607.

39. Paul, D. and Nair, S., Stress adaptations in a plant growth promoting rhizobacterium (PGPR) with increasing salinity in the coastal agricultural soils. J. Basic Microbiol., 2008, 48, 378-384.

40. Bogino, P. C., Oliva, M. M., Sorroche, G. F. and Giordano, W., The role of bacterial biofilms and surface components in plantbacterial associations. Int. J. Mol. Sci., 2013, 14, 15838-15859.

Received 18 July 2017; revised accepted 14 May 2020

doi: $10.18520 / \mathrm{cs} / \mathrm{v} 119 / \mathrm{i} 7 / 1197-1204$

\section{First fossil dragonfly from India}

\section{Manoshi Hazra ${ }^{1,2}$, Taposhi Hazra ${ }^{1}$, Subhankar Kumar Sarkar ${ }^{3}$, Subir Bera ${ }^{4}$ and Mahasin Ali Khan ${ }^{1, *}$}

${ }^{1}$ Palaeobotany-Palynology Laboratory, Department of Botany, Sidho-Kanho-Birsha University, Ranchi Road, Purulia 723 104, India ${ }^{2}$ Presidency University, 86/1, College Street, Calcutta University Road, Kolkata 700 073, India

${ }^{3}$ Entomology Laboratory, Department of Zoology,

University of Kalyani, Kalyani, Nadia 741235 , India

${ }^{4}$ Centre of Advanced Study, Department of Botany,

University of Calcutta, 35, B.C. Road, Kolkata 700 019, India

In the Indian wetland palaeoecosystem, no dragonfly has been reported from the Cenozoic sediments until now. Here, we report a well-preserved fossil dragonfly (Odonata: Anisoptera) recovered from the late Neogene sediments of the Chotanagpur plateau, Jharkhand, eastern India. It is characterized by

*For correspondence. (e-mail: khan.mahasinali@gmail.com) 